\title{
MESOPTYCHIA IGIANA (S.HATT.) L.SÖDERSTR. ET VÁŇA (JUNGERMANNIACEAE, MARCHANTIOPHYTA) IN RUSSIA
}

\section{MESOPTYCHIA IGIANA (S.HATT.) L.SÖDERSTR. ET VÁŇA (JUNGERMANNIACEAE, MARCHANTIOPHYTA) В РОССИИ}

\author{
AleXey D. Potemkin ${ }^{1}$, Yuriy S. MAMONTOV ${ }^{1,2,3}$, ElEnA V. SOFRONOVA ${ }^{4} \&$ \\ OXANA I. KUZNETSOVA ${ }^{3}$ \\ АЛЕКСЕЙ Д. ПОТЕМКИН ${ }^{1}$, ЮРИЙ С. МАМОНТОВ ${ }^{1,2,3}$, ЕЛЕНА В. СОФРОНОВА $^{4}$, \\ ОКСАНА И. КУЗНЕЦОВА ${ }^{3}$
}

Abstract

\begin{abstract}
Mesoptychia igiana was recorded for the first time for Russia from Republic of Buryatia from South Muya Range of Stanovoye Nagor'e Uplans, and from Kropotkin Range of East Sayan Mts., on the basis of comparison with protologue and the holotype. This species has been previously known from southern Japan and China only. The species has coarsely and densely papillose cuticle, with strongly protruding hemisphaerical papillae that are not characteristic of the other species of the genus. Description and illustrations of Russian plants, their ecology, differentiation from the other species of the genus and, particularly, from M. kateninii (Schljakov) Potemkin, Mamontov \& Sofronova, comb. nov., and distinctions from the holotype are provided. Molecular comparison of $r b c \mathrm{~L}$ sequences of Siberian specimens of $M$. igiana has shown their isolated position from the other Mesoptychia species sequences presently deposited in GenBank.
\end{abstract}

Резюме

В сборах из Бурятии - со Станового Нагорья и Восточного Саяна - выявлен неизвестный ранее в России вид рода Mesoptychia. Сравнение с протологом и голотипом всточноазиатского вида $M$. igiana позволило отнести находку именно к этому таксону. Ранее он был известен только из Южной Японии и Китая. M. igiana характеризуется густо грубопапиллозной кутикулой с полусферическими папиллами, не свойственными другим видам рода. Приводятся описание, иллюстрации, характеристика экологии и отличий M. igiana от других видов рода, в том числе описанной с Восточной Чукотки M. kateninii (Schljakov) Potemkin, Mamontov \& Sofronova, comb. nov. Сравнение последовательностей $r b c \mathrm{~L}$ сибирских представителей $M$. igiana показало их изолированное положение от других видов рода, данные о которых в настоящее время размещены в Генбанке.

KEYWORDS: liverworts, taxonomy, Jungermanniaceae, Mesoptychia, Republic of Buryatia, Baikal Siberia, Russia, $r b c \mathrm{~L}$.

\section{INTRODUCTION}

The genus Mesoptychia (Lindb.) A.Evans was distinguished by Lindberg in Lindberg \& Arnell (1889) as section Mesoptychia Lindb. within the genus Jungermannia L. that was raised to the generic level by Evans (1903). Until recently, the genus was circumscribed as monotypic with one species, M. sahlbergii (Lindb.) A.Evans. Consideration of most species of Leiocolea (Müll.Frib.) $\mathrm{H}$ Buch in the molecular analyses (Yatsentyuk et al., 2004; De Roo et al., 2007; Vilnet et al., 2009, 2010) has shown phylogenetic position of $M$. sahlbergii among them, which resulted in transfer of all Leiocolea species to the earlier described genus Mesoptychia (Váňa et al., 2012).
On the basis of the molecular analysis, Leiocolea borealis (Frisvoll \& Moen) L Söderstr. is treated as Gymnocolea borealis (Frisvoll \& Moen) R.M.Schust. (Cailliau et al., 2013).

The genus Mesoptychia sensu Váňa et al. (2012) has Holarctic distribution and apparently the East Asian origin with highest species diversity there. About 20 mainly calciphilous species have been known in Mesoptychia. Seven species have nearly circumpolar northern ranges, whereas the rest have \pm restricted distribution in both southern and temperate regions of Holarctic, mostly in East Asia (Schumacker \& Váňa, 2005; Yamada \& Iwatsuki, 2006; Potemkin \& Sofronova, 2009).

\footnotetext{
1 - V.L. Komarov Botanical Institute, Russian Academy of Sciences, 2 Prof. Popov Str., St. Petersburg, 197376 Russia; e-mail: Potemkin_alexey@mail.ru

2 - Polar-Alpine Botanical Garden, Kola Science Centre, Russian Academy of Sciences, Kirovsk-6, Murmansk Province, 184256 Russia; e-mail: yur-mamontov@yandex.ru

3 - Tsitsin Main Botanical Garden, Russ. Acad. Sci, 4 Botanicheskaya Str. , Moscow, 127276 Russia.

4 - Institute for Biological Problems of Cryolithozone SB RAS, 41 Lenin Str., Yakutsk, 677980 Russia; e-mail: soflena@mail.ru
} 
Most species of Mesoptychia have moderately to faintly papillose cuticle, obliquely inserted leaves with shallow sinuses, 1(-3)-lobed underleaves and cylindric perianth \pm contracted in \pm distinct beak. The latter characters, however, are not developed in the type species of the genus, $M$. sahlbergii, distinct from the other species of the genus in having a long marsupium and a reduced perianth gradually narrowed to the mouth (Lindberg \& Arnell, 1889), not characteristic of M. morrisoncola (Horik.) L.Söderstr. \& Váňa and M. mayebarae (S.Hatt.) L.Söderstr. et Váňa. Except four paroicous species, namely, the circumpolar M. gillmanii (Austin) L.Söderstr. \& Váňa and M. rutheana (Limpr.) L.Söderstr. \& Váňa, the East Asian M. ussuriensis (Bakalin) L.Söderstr. \& Váňa and Californian M. polymorpha Stotler, Crand.-Stotl. \& Bakalin, the Mesoptychia species are dioicous. Gemmae production is known for M. heterocolpos (Thed. ex Hartm.) L.Söderstr. et Váňa only. The facts of morphological diversity of the genus and sharp morphological separation of its most species from each other support their long-standing separation and considerable age of the genus.

Identification of collections from highlands of the Republic of Buryatia (Baikal Siberia, Russia) resulted in a finding of unknown Mesoptychia species, which we failed to identified by a number of treatments. It differs from of the northern Holarctic species in having densely and coarsely papillose cuticle with mainly rounded papillae in the leaf middle and often protruding papillae along the margins, particularly, in apical leaf sector, and also having mostly concave leaves about as wide as long with subrectangular sinus often contracted to the base and then slightly deflexed and often apiculate lobes, rather frequent formation of rhizoids from ventral leaf base resulting in their fasciculate distribution along the stem. Moreover postical and in less extent antical leaf margins near the base are without chloroplasts and oil bodies in fresh material or empty in dead leaves. This persuaded us to make a molecular study of the specimens, which however has shown an isolated position of Buryatian plants from all Mesoptychia species available in GenBank (see below). The further search in adjacent regions and comparison with protologue and holotype of Lophozia igiana S.Hatt. from South Japan (Hattori, 1956) allowed us to identify the Siberian plants as this species, now treated in the genus Mesoptychia, M. igiana (S.Hatt.) L.Söderstr. et Váňa.

\section{MATERIALS AND METHODS}

To test phylogenetic relation of Mesoptychia igiana, the majority of species of the genus Mesoptychia sensu Váňa et al. (2012) were analyzed. The genus Jungermannia L. (J. atrovirens Dumort. and J. exsertifolia (Steph.) subsp. cordifolia (Dumort.) Ván̆a) was chosen as an outgroup as most closely related to Mesoptychia (Vilnet et al., 2010). In general, 19 sequences were taken from GenBank and analyzed (Appendix 1).
Two new cpDNA $r b c \mathrm{~L}$ sequences were generated from our two specimens of $M$. igiana. Our attempts to obtain rps 4 sequences for additional comparison were unsuccessful. Plant tissues were isolated from herbarium collections. Total genomic DNA was purified using CTABmethod prior to amplification. Protocols for PCR were carried out as described in Wilson et al. (2004) and Groth $\&$ Heinrichs (2005). Only $r b c$ L nucleotide sequence data were used for the phylogenetic analysis. The sequences were aligned manually in MEGA version 6.0 (Tamura et al., 2013). Ambiguous positions were excluded from the alignment and lacking parts of sequences were coded as missing. Maximum parsimony (MP) analysis was carried out with PAUP* version 4.0b10 (Swofford, 2000).

MP heuristic searches were conducted with the following options: heuristic search mode, 100 random-addition-sequence replicates, tree bisection-reconnection (TBR) branch swapping, MULTrees option on, and collapse zero-length branches off. All characters were treated as equally weighted and unordered. Branch support was assessed using 1000 non-parametric bootstrap resamplings (Felsenstein, 1985) with each bootstrap replicate carried out as heuristic search with 100 RAS and TBR. Bootstrap percentage values (BSP) above 70 were regarded as good support (Hillis \& Bull, 1993). Where more than one most parsimonious tree was found, trees were summarized in a strict consensus tree.

\section{RESULTS}

In the phylogenetic tree (Fig. 1), two specimens of $\mathrm{Me}$ soptychia igiana from Russia formed a highly supported subclade within a basal clade; this clade includes also $M$. bantriensis, $M$. collaris, $M$. gillmanii, $M$. heterocolpos var. harpanthoides, M. fitzgeraldiae, and M. morrisoncola, and highly supported subclades of two specimens of M. badensis and two specimens of M. rutheana.

In general, obtained MP topology confirms the separate position of $M$. igiana at species level and correctness of treatment of Lophozia igiana as a member of the genus Mesoptychia sensu Váňa et al. (2012). On the other hand, existence of $M$. heterocolpos challenges the treatment of that genus as monophyletic. Frequent gemmae formation in M. heterocolpos, unlike all other Mesoptychia, in combination with highly supported $(\mathrm{MP}=100)$ differences in $r b c \mathrm{~L}$ sequences, point at the necessity of separation of $M$. heterocolpos at subgeneric or even generic level. That matter needs further taxonomic study.

\section{TAXONOMIC TREATMENT}

Mesoptychia igiana (S. Hatt.) L. Söderstr. \& Váňa, Phytotaxa 65: 54. 2012. - Lophozia igiana S.Hatt., J. Jap. Bot. 31: 201. 1956. - Leiocolea igiana (S.Hatt.) Inoue, J. Hattori Bot. Lab. 25: 190. 1962. Figs. 2-4.

Holotype: Japan, Takushima Pref., Mt. Tsurugi, 1740 m alt., on humus among limestones, with Mnium laenerve, Myurella sibirica, Aug. 13, 1954, T. Kodama 7248 (NICH)! 


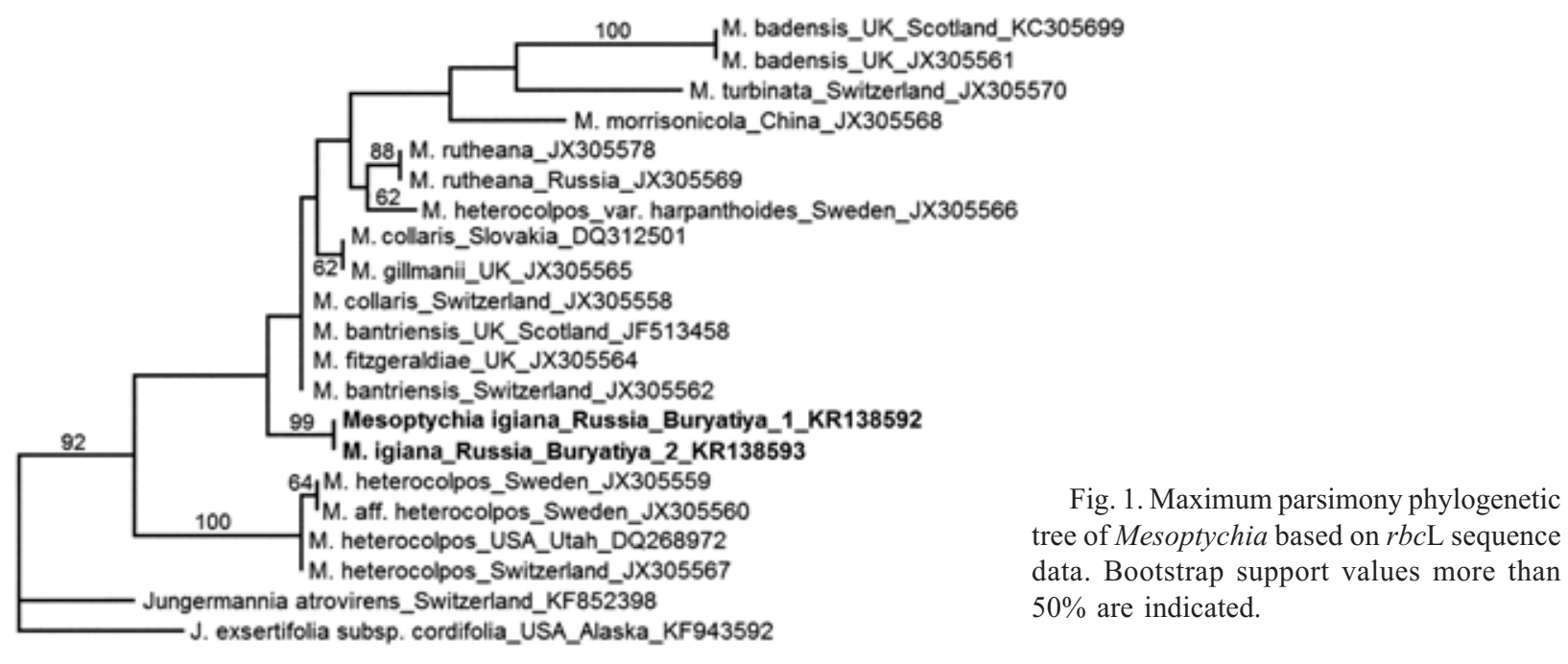

Plants in extensive loose patches or as admixture among other bryophytes, from olive or brownish green to nearly black, creeping to ascending; shoots with leaves $0.4-3 \mathrm{~cm}$ long and (0.7-)0.8-1(-1.2) mm wide. Stem in cross section with $2(-3)$-stratose indefinitely demarcated cortex of thick-walled, \pm isodiametric or slightly tangentially flattened cells; surface of cortical cells indistinctly to distinctly papillose, rarely smooth; median cells slightly larger than cortical ones or similar in size, thin- to slightly thick-walled. Rhizoids rather abundant, developed from postical surface of stem and rather often from separate cells of postical leaf base and underleaf base, sometimes in fascicles from leaf and underleaf base. Leaves mainly bilobed (few trilobed leaves were seen), with \pm shorter antical lobe, \pm obliquely inserted, contiguous to remote, with not or slightly decurrent antical margin, distinctly concave and turned to the antical side or almost to totally plane in mod. laxifolia, nearly symmetrical to somewhat asymmetrical and then with somewhat broader and longer postical leaf margin, \pm broadly ovate and broadly trapezoid, (480-)530-830(-1000) $\mu \mathrm{m}$ long, (520-)550$920(-1100) \mu \mathrm{m}$ wide, variable from one specimen to another, mostly about as wide as long, sometimes longer than wide or wider than long, $(0.75-) 0.9-1.1(-1.25)$ times as wide as long; both leaf margins at least somewhat convex; postical leaf margin is a little stronger convex, its base strongly rounded and devoid chloroplasts and oil bodies; lobes mostly apiculate with uniseriate apiculis of $1-4(-5)$ subisodiametric cells and subisodiametric to spinose terminal cell up to 3 times as long as wide, rarely acuminate, blunt or nearly round, usually with \pm convex, rarer straight or concave inner margins. Sinus usually acute subrectangular and often somewhat constricted to the base and slightly reflexed, sometimes round rectangular, obtusely angled to nearly lunate or acute angled, $0.20-0.30(-0.37)$ the leaf length. Median leaf cells in undivided part of leaf nearly isodiametric, (14-)16-22($28) \times(15-) 20-28(-30) \mu \mathrm{m}$, with large bulging to acute trigones, sometimes with distinct middle lamellae; cell walls often \pm brown. Oil bodies finely granulate, greyish, 2-4(-6) per leaf cell, round, (3-)4-7.5 $\mu \mathrm{m}$ and oval to broadly fusiform, 7-10×5-6 $\mu \mathrm{m}$, soon disintegrating, in all leaf cells except marginal and submarginal cells near postical and sometimes antical leaf base. Leaf surface usually coarsely papillose, with numerous irregular hemispherical papillae throughout, often protruding along margins in apical leaf sector particularly, $3-7(-10) \mu \mathrm{m}$ in diam. in the leaf middle, smaller to the margins; near to the base or sometimes in the lower part or rarely even in the lower half of the leaf papillae elliptic to sometimes along postical margin long narrow sausage-like, subparallel and located very close to each other, up to $25-95 \times 5-$ $7 \mu \mathrm{m}$. Underleaves rather small to large and distinct, $260-480(-600) \mu \mathrm{m}$ long, 5-9(-15) cells at the base, gradually tapering in usually long uniseriate apical part, with cilia and/or slime papillae on both margins; a few very large oblong but tapered to the apex underleaves were seen, 650-700 $\mu \mathrm{m}$ long, 12-15 cells wide; cilia divergent from underleaf margins at acute angle; at the base often bistratose or swollen with fascicule of rhizoids. Dioicous. Androecia spicate intercalary of 5-7 pairs longitudinally folded and concave bracts similar to sterile leaves in size and shape, unknown in Siberian plants. Antheridia not preserved in the holotype. Plants with unfertilized gynoecia with (1-)2 subfloral innovations below perianth. Perianth almost wholly emergent, rather easily detached when sterile, pyriform, very slightly plicate, rather suddenly contracted to the mouth; mouth shortly and distinctly or indistinctly beaked, in holotype dentate-ciliate with 1-2-celled long teeth, cells near the mouth elongate striate-verrucose, $13-16 \times 25-40 \mu \mathrm{m}$, in Siberian plants perianth mouth longly ciliate, with cilia $(3-) 4(-5)$ cells long, with terminal cells often smooth, $40-55 \times 12-15(-17) \mu \mathrm{m}$. Female bracts similar to leaves but slightly larger than leaves, (2-)3-lobed (antical lobes far smaller than others); bracteole distinct, \pm larger than underleaves, lanceolate, unequally 2-lobed or oblong or subulate. 


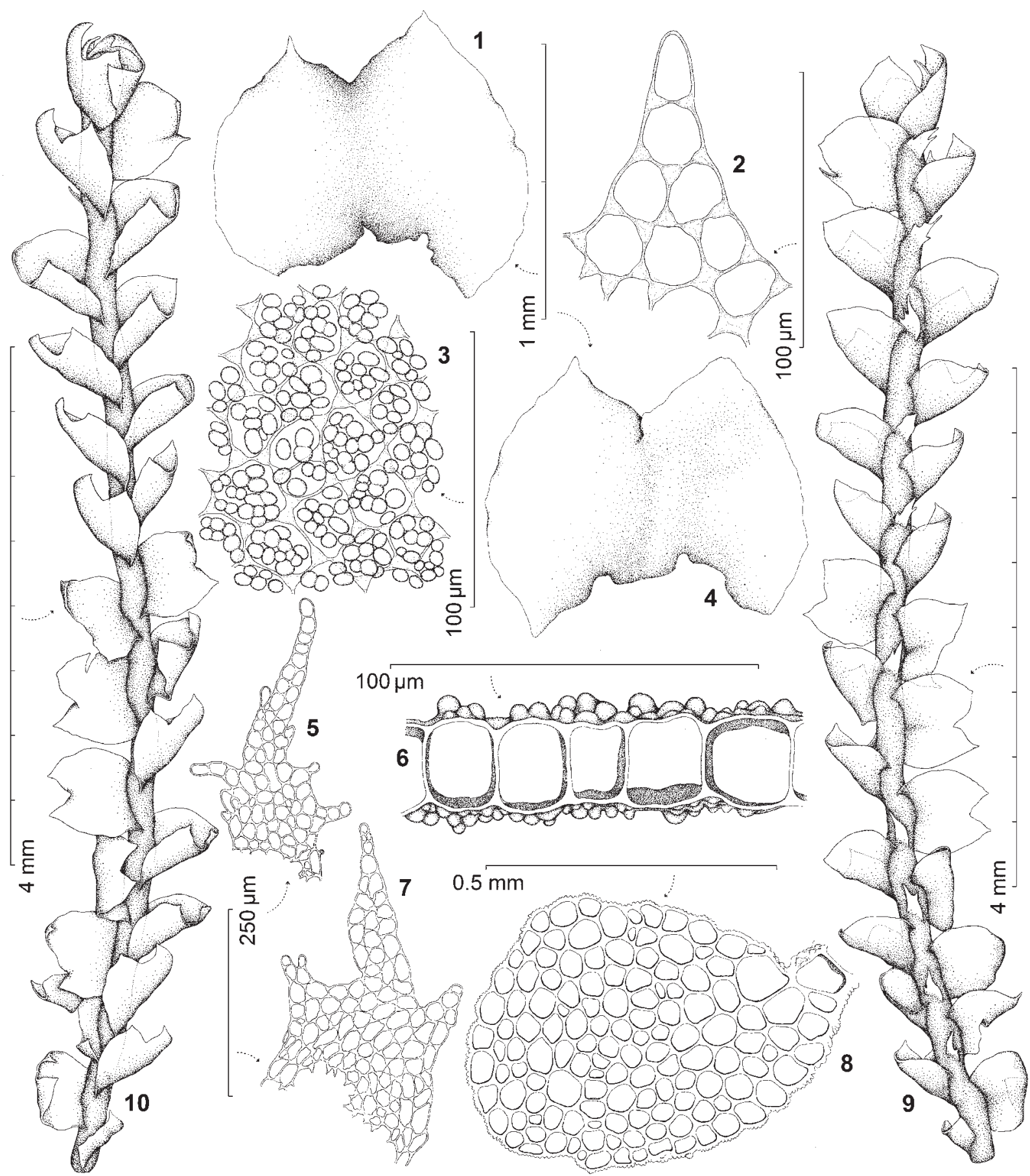

Fig. 2. Mesoptychia igiana: 1, 4- leaves; 2 - leaf lobe apex; 3 - leaf cells with coarse papillose cuticle indicated; 5, 7 - underleaves; 6 - leaf cross section; 8 - stem cross section; 9 - habit, ventral view; 10 - the same, dorsal view. All from Buryatia, Russia, Mamontov 392-3 (LE).

Ecology. In Stanovoye Nagor'e Uplans, Mesoptychia igiana was collected mostly in Pinus pumila-dominated communities associated with Alnus fruticosa, Betula rotundifolia, Bergenia crassifolia, Dryas spp., Ledum palustre and Rhododendron adamsii, occupying rocky slope in forest-tundra belt; altitude range is from 1475 to $1798 \mathrm{~m}$ a.s.l. In these communities, Mesoptychia igiana was found on moist shaded rocks in brook bed, on soil-covered rock ledges on bank of waterfall, and in wet niche between rocks on high rocky slope, together with calciphilous and $\mathrm{Ca}$-tolerant hepatics, namely, Blepharostoma trichophyllum (L.) Dumort. var. brevirete Bryhn \& Kaal., Radula prolifera Arnell and Jungermannia cf. borealis Damsh. et Váňa. In East Sayan Mts., Mesoptychia igiana was collected in Salix spp.-Rhododendron adamsii-Bergenia crassifolia-Dryas sp.grass community occupying rocky slope in alpine belt; the altitude was $1986 \mathrm{~m}$ a.s.l. It grew in large pure patches or together with Blepharostoma trichophyllum var. brevirete 


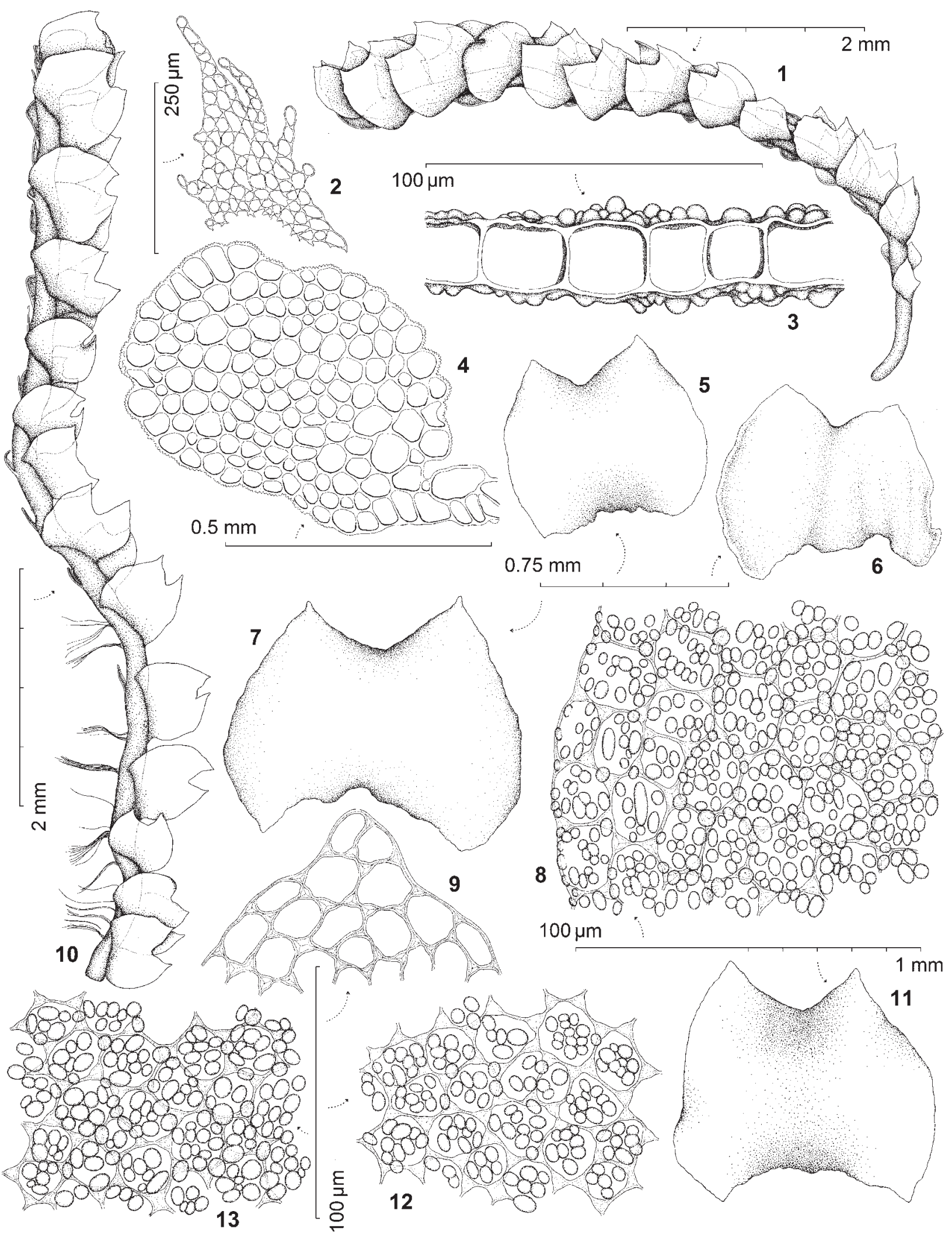

Fig. 3. Mesoptychia igiana: 1 - habit, lateral aspect; 2 - an underleaf; 3 - leaf cross section; 4 - stem cross section; 5-7, 11 leaves; 8, 12, 13 - leaf cells with coarse papillose cuticle indicated; 9 - leaf lobe apex; 10 - habit, lateral view. All from Russia, Buryatia, Mamontov 392-3 (LE). 


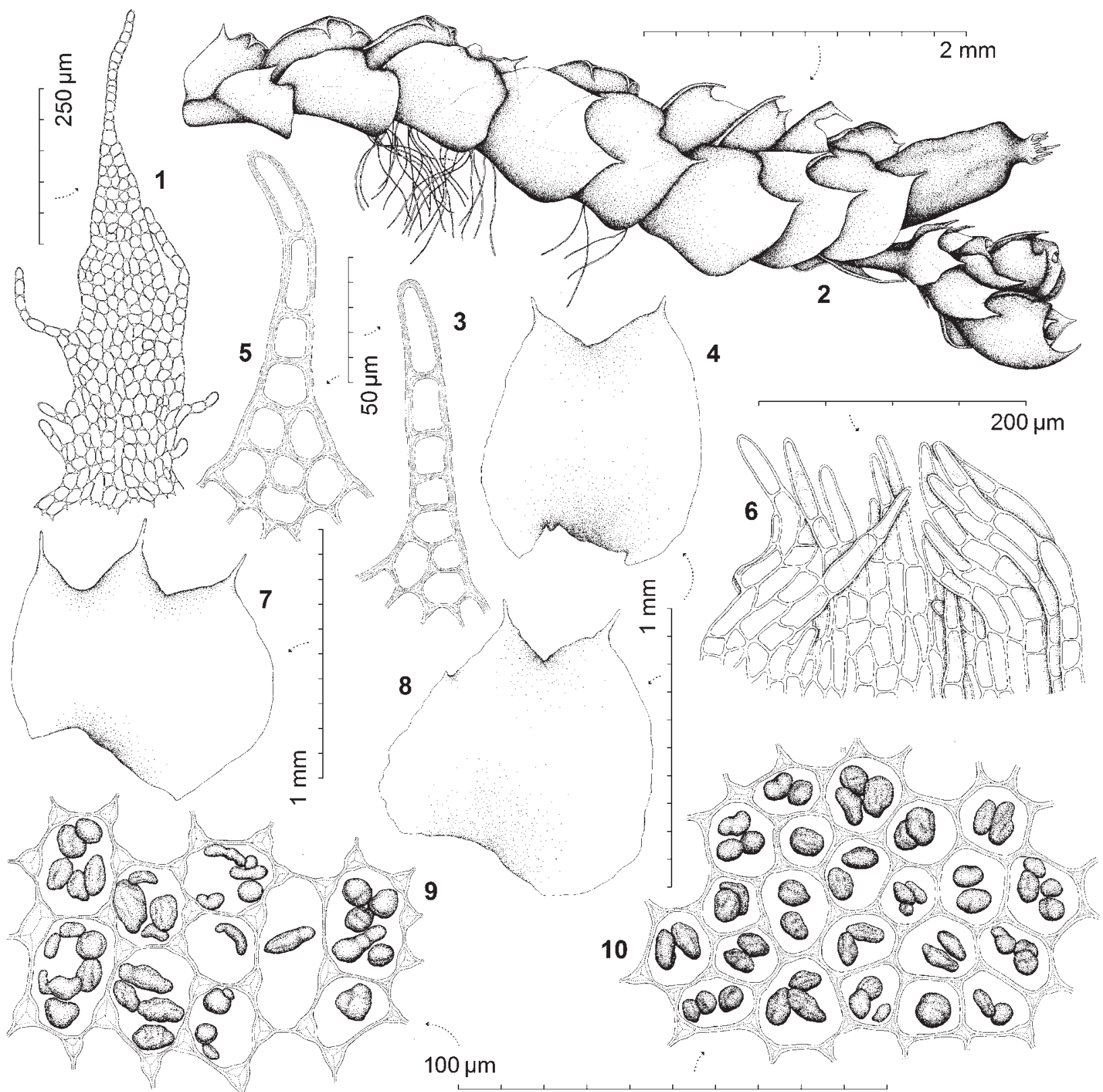

Fig. 4. Mesoptychia igiana: 1 - female bracteole; 2 - female plant with a perianth and two subfloral innovations; 3,5 - leaf lobe apices; 4 - stem leaf; 6 - perianth mouth with cells indicated; 7, 8 - female bracts; 9 - cells of leaf base with oil bodies indicated; 10 - cells of leaf middle with oil bodies indicated. All from Russia, Buryatia, Mamontov 548-2 (LE).

on moist rocks in canyon, in partial shade. According to the label data, Japanese plants grew on moist shaded calcareous rocks and humus over them at high altitudes (up to $1748 \mathrm{~m}$ a.s.l.). Plants from the type specimen were collected together with Mnium laevinerve Cardot, Myurella sibirica (Müll.Hal.) Reimers, Conocephalum conicum (L.) Dumort., Mesoptychia morrisoncola (as Lophozia diversiloba S.Hatt.) and Orthothecium rufescens (Dicks. ex Brid.) Bruch et al. (Hattori, 1956).

Distribution. Russia (Republic of Buryatia), China (Sichuan (Wu, 2000) and Yunnan (Piippo et al. 1998; Gao \& Cao 2000; Wu, 2000), Japan (Honshu, Shikoku).

Specimens examined. Japan. Takushima Pref., Mt. Tsurugi, $1740 \mathrm{~m}$ alt., on humus among limestones, with Mnium laenerve, Myurella sibirica, Aug. 13, 1954, T. Kodama 7248 (Holotype - NICH). Russia. Republic of Buryatia: Kurumkan District, Stanovoye Nagor‘e Uplans, South Muya Range, Dzherginskiy State Reserve, Barguzin River valley, near Lake Balan-Tamur, $55^{\circ} 12^{\prime} 26.3^{\prime \prime} \mathrm{N}, 111^{\circ} 41^{\prime} 41.9^{\prime \prime} \mathrm{E}, 1475 \mathrm{~m}$ alt., 3.VIII.2013, Mamontov 392-3 (LE, KPABG, MHA, SASY, NICH, TNS); $i b$., upper of Barguzin River, $55^{\circ} 07^{\prime} 45.5^{\prime \prime} \mathrm{N}$., 111 ${ }^{\circ} 53^{\prime} 6.0$ " E., $1618 \mathrm{~m}$ alt., 1.VIII.2013, Mamontov 384-6 (LE, KPABG, MHA, SASY, NICH, TNS); $i b ., 55^{\circ} 07^{\prime} 24.2^{\prime \prime}$ N., 111'52'58.2" E., $1798 \mathrm{~m}$ alt. 1.VIII.2013, Mamontov 386-2 (LE, KPABG, MHA, SASY, NICH, TNS); ib., 1.VIII.2013, Mamontov 386-5 (LE, KPABG, MHA, SASY, NICH, TNS); Okinsky District, East Sayan Mts., Kropotkin Range, upper of Obtoy River, 5249’28.3” N 99²9’06.5” E, 1986 m alt., 9.VII.2015, Mamontov 548-2, per. (LE, KPABG, MHA, SASY, NICH, TNS). 
Comparison of Siberian plants with the holotype. The holotype of Lophozia igiana contains about a dozen of repeatedly studied yellowish brown plants, including plants with juvenile perianth and androecia. Siberian plants share with the holotype the shape of leaves, with characteristically apiculate lobe apices, shape and size of underleaves, cell size, coarsely papillose leaf surface, sporadic fasciculate rhizoids originating from the leaf base. They differ from the holotype in colour (olive fuscous to green vs. yellowish brown) and sinus shape (often constricted to the base and somewhat deflexed vs. mostly not constricted to the base and not deflexed, subrectangular to rounded at the base and lunate), perianth mouth with cilia 3-4(-5) cells long vs. 1-2 cells long with longer terminal and subterminal cells $(40-50 \mu \mathrm{m}$ vs. $25-40 \mu \mathrm{m}$ long). Despite mentioned colour dissimilarity noted for the holotype according to the published descriptions, Japanese plants vary from olive green and yellowish brown to olive brown (Hattori, 1956; Kitagawa, 1966). Colour difference may be caused by different conditions of growth. The other distinctions are features of the northern population of this species. Their significance appears to be infraspecific but at present cannot be evaluated properly.

Differentiation. The most valuable diagnostic character of $M$. igiana is densely and coarsely papillose leaf surface. No other species of the genus Mesoptychia have such regular and numerous large rounded papillae on the leaf surface. It results in characteristic opaque appearance of plants when investigated under dissecting stereomicroscope. It should be noted that leaf surface may be almost smooth in several (or most of) leaves of the same plant, especially towards the shoot base. On the other hand, the uppermost leaves, as a rule, form a coarsely papillose surface. Other important diagnostic characters of $M$. igiana are mostly concave leaves with apiculate lobes and subrectangular, often constricted at the base sinuses, marginal area of postical leaf base without chloroplasts and oil-bodies and often fasciculately distributed rhizoids. When dry, pigmented plants often look blackish or olive green due to brown pigmented cell walls. $M$. igiana recalls in habitus M. kateninii (Schljakov) Potemkin, Mamontov \& Sofronova comb. nov. (三Leiocolea kateninii Schljakov, 1978. Novosti Sist. Nizsh, Rast. 15: 244. Typus: Pars orientalis paeninsulae Tschukotka, sinus Laurenii in viciniis promotorii Krausei, tundra dryadoso-lichenoso-muscosa cum Cassiope ericoidi et ceteris, ad solum calcareumn, 9.VII.1974, Katenin No. 21, LE). Mesoptychia kateninii has leaves rather similar in shape: concave but in general narrower, with subrectangular or obtuse-angled, often constricted to the base sinuses and apiculate lobes. It was described from East Chukotka, Far Eastern Arctic, as a species of subgenus Hattoriella (Inoue) Schljakov due to perianths without beak that have much in common with immature perianths of $M$. igiana in its holotype. M. kateninii differs from $M$. igiana in considerably larger cells, different cu- ticle with flat elliptic papillae and narrower leaves (Schljakov, 1978: Fig. 2). Taxonomic significance of these distinctions is a subject of further research when additional collections of both species will be available. Distinguishing of M. kateninii which has narrowly lanceolate to subulate underleaves and coarse bulging trigones as a synonym of M. badensis (Bakalin, 2003), on the basis of overlapping characters appears to be insufficiently warranted and needs further investigation.

Phytogeographic and ecological peculiarities. Important characteristics of Siberian population of Mesoptychia igiana are altitudinal position and corresponding conditions of growth. Plants of the species from south Japan (Honshu, Shikoku) were recorded from shaded and/ or moist humus-covered limestones or from humus among limestones at forested mountain territories at rather high altitudes, mostly up to $1740 \mathrm{~m}$, whereas all Siberian collections made about $15-19^{\circ}$ northward were gathered approximately at the same altitudes and therefore in more severe conditions. Southernmost collections of $M$. igiana have been made by T. Koponen and X.-J. Li in Yunnan, near Lijiang, along "White Water" River bed surrounded by Pinus tabulaeformis var. dentata forest, 2800$2850 \mathrm{~m}$ altitude, $27^{\circ} 08^{\prime} \mathrm{N}, 100^{\circ} 14^{\prime} \mathrm{E}$ (Piippo et al., 1998), i.e. about $28^{\circ}$ southward from the northern sampling site in Siberia.

It should be noted that $M$. igiana is known in Russia only in South Muya Range of the Stanovoy'e Nagor'e Uplands and on Kropotkin Range of the East Sayan Mts. Our special attempts in searching for new localities of the species in $\mathrm{Ca}$-rich rocky areas in other ranges of Stanovoy'e Nagor'e Uplands (the Kalar, Kodar and Udokan Ranges) and East Sayan Mts. have been unsuccessful.

In general, the distribution of $M$. igiana is similar to that of Anastrophyllum ellipticum Inoue, which is also known from the high mountains of Japan (Inoue, 1976), China (Long, 2011), and from a single locality in Katunskiy Range of Altai Mts., South Siberia (Mamontov \& Vilnet, 2013). Absence of their records from northern mountain humid areas of East Siberia and Russian Far East indicates the East Asian origin of these two species, and their Siberian locations could be explained by relict nature. The Siberian populations of both species occur in rather warm and humid environmental conditions in high mountains of South Siberia and formed, probably, during the period of global climatic changes and increase of Eurasian mountain systems in Pleistocene.

\section{ACKNOWLEDGEMENTS}

We are grateful to M. Mizatani (NICH) for sending us the holotype of Lophozia igiana and to R.-L. Zhu for tracing of presently known distribution of Mesoptychia igiana in China. N.A. Konstantinova and E.A. Borovichev are kindly thanked for help with literature. Special thanks are to Yu.B. Okolodkov for correcting the English. The anonymous reviewers are gratefully acknowl- 
edged for valuable comments and advice. Help of V.F. Malysheva and E.F. Malysheva with molecular studies of Mesoptychia igiana is highly appreciated. The study of ADP was carried out within the framework of the institutional research project 01201255616 of the Komarov Botanical Institute of the Russian Academy of Sciences (RAS). The work of ADP and EVS was partly supported by RFBR 15-44-05134 and by the State Program on the project 52.1.11 "The diversity of flora of taiga zone of Yakutia: the structure, dynamics, conservation" (a 0376-2014-002). The work of YSM was partly supported by the RAS Program "Biodiversity"RFBR 13-0401427, 15-04-03479, 15-29-02647, 15-34-50938.

\section{LITERATURE CITED}

BAKALIN, V.A. 2003. The status and treatment of the genus Hattoriella (H. Inoue) H. Inoue. - Arctoa 12: 91-97.

CAILLIAU, A., D.G. LONG, M.J. PRICE \& M. PERRET. 2013. Phylogeny and systematic position of Mesoptychia (Lindb.) A. Evans. - Plant Systematics and Evolution 299: 1243-1251.

DE ROO, R.T., T.A. HEDDERSON \& L. SÖDERSTRÖM. 2007. Molecular insights into the phylogeny of the leafy liverwort family Lophoziaceae Cavers. - Taxon 56(2): 301-314.

EVANS, A. 1903. Yukon Hepaticae. - Ottawa Naturalist 17: 13-24.

FELSENSTEIN, J. 1985. Confidence limits on phylogenies: an approach using the bootstrap. - Evolution 39: 783-791.

GAO, C. \& CAO T. (eds.). 2000. Flora Yunnanica 17. - Science Press, Beijing.

GROTH, H. \& J. HEINRICHS. 2005. Maximum likelihood analyses of chloroplast gene $r b c \mathrm{~L}$ sequences indicate relationships of Syzygiella (Jungermanniopsida) with Lophoziaceae rather than Plagiochilaceae. - Cryptogamie, Bryology 26: 49-57.

HARTMANN, F.A., R. WILSON, S.R. GRADSTEIN, H. SCHNEIDER, J. HEINRICHS. 2006. Testing hypotheses on species delimitations and disjunctions in the liverwort Bryopteris (Jungermanniopsida: Lejeuneaceae). - International Journal of Plant Sciences 167: 1205-1214.

HATTORI, S. 1956. Notula de Hepaticae Japonicis (18). - The Journal of Japanrse Botany 7: 201-204.

HILLIS, D.M. \& J.J. BULL. 1993. An empirical test of bootstrapping as a method for assessing the confidence in phylogenetic analysis. - Systematic Biology 42: 182-192.

INOUE, H. 1978. Anastrophyllum ellipticum Inoue (sp. nov., Hepaticae) from Japan. - Bulletin of the National Science Museum. Series B, Botany 4: 13-17.

LONG, D.G. 2011. Bryophyte exploration of South-west Sichuan, China. - Field Bryology 103: 32-39.

KITAGAWA, N. 1966. A revision of the family Lophoziaceae of Japan and its adjacent regions. II. - The Journal of the Hattori Botanical Laboratory 29: 101-149.

LINDBERG, S.O. \& H.W. ARNELL. 1889. Musci Asiae borealis. I. Lebermoose. - Kongliga Svenska Vetenskaps-Akademien Handlingar 23(5): $1-69$.

MAMONTOV, YU.S. \& A.A. VILNET. 2013. Anastrophyllum ellipticum Inoue (Jungermanniales, Marchantiophyta), a new species for Russian liverwort flora. - Arctoa 22: 151-158.

PIIPPO, S., X.-L. HE, T. KOPONEN, P. J. REDFEARN Jr. \& X.-J. LI. 1998. Hepaticae from Yunnan, China with a checklist of Yunnan Hepaticae and Anthocerotae. - Journal of the Hattori Botanical Laboratory 84: $135-158$.

[POTEMKIN, A.D. \& E.V. SOFRONOVA] ПОТЁМКИН А.Д., Е.В. СОФРОНОВА. 2009. Печеночники и антоцеротовые России. Т. 1. - [Liverworts and hornworts of Russia Vol. 1] СПб., Бостон-спектр [St. Perersburg, Boston-spectr], $368 \mathrm{pp}$.
[SCHLJAKOV, R.N. ] ШЛЯКОВ Р.Н. 1978. Новые виды печеночников из Сибири и Дальнего Востока. - [New species of hepatics from Sibreria and Far East] Новости систематики низиих растений [Novosti Sistematiki Nizshikh Rastenij] 15: 242-247.

SCHUMACKER, R. \& J. VÁŇA. 2005. Identification keys to the liverworts and hornworts of Europe and Macaronesia (distribution and status). $2^{\text {nd }}$ edition fully revised and updated. - Poznan, Sorus, $209 \mathrm{pp}$.

SWOFFORD, D.L. 2000. PAUP*, Phylogenetic analyses using parsimony (* and other methods), Version 4.01b10. - Sinauer Associates, Sunderland, $M A$.

TAMURA, K., G. STECHER, D. PETERSON, A. FILIPSKI, S. KUMAR. 2013. MEGA6: Molecular Evolutionary Genetics Analysis version 6.0. - Molecular Biology and Evolution: 30: 2725-2729.

VÁŇA, J., L. SÖDERSTRÖM, A. HAGBORG \& M. VON KONRAT. 2012. Notes on early land plants today. 8 . New combinations and some lectotypifications in Mesoptychia. - Phytotaxa 65: 52-56.

VILNET, A.A., N.A. KONSTANTINOVA \& A.V. TROITSKY. 2009. Genosystematics and new insights on phylogeny and taxonomy of livereworts. - Molecular Biology: 43(5): 1-12.

VILNET, A.A., N.A. KONSTANTINOVA \& A.V. TROITSKY. 2010. Molecular insight on phylogeny and systematics of the Lophoziaceae, Scapaniaceae, Gymnomitriaceae and Jungermanniaceae. - Arctoa 19:31-50.

WILSON, R., S.R. GRADSTEIN, J. HEINRICHS, H. GROTH, A.L. ILKIU-BORGES \& F.A. HARTMANN. 2004. Phylogeny of Lejeuneaceae: A cladistic analysis of chloroplast gene $r b c \mathrm{~L}$ sequences and morphology with preliminary comments on the mitochondrial nad4-2 spacer region. - Monographs in Systematic Botany from the Missouri Botanical Garden 98: 189-202.

WU, P.-C. (ed.). 2000. Bryoflora of Hengduan Mts. (Southwest China). IXVIII. - Beijing, Science Press, 742 pp.

YAMADA, K.\& Z. IWATSUKI. 2006. Catalog of the hepatics of Japan. Journal of the Hattori Botanical Laboratory 99: 1-106.

YATSENTYUK, S.P., N.A. KONSTANTINOVA, M.S. IGNATOV, J. HYVÖNEN \& A.V. TROITSKY. 2004. On phylogeny of Lophoziaceae and related families (Hepaticae, Jungermanniales) based on $\operatorname{trn} \mathrm{L}-$ $\operatorname{trn} \mathrm{F}$ intron-spacer sequences of chloroplast DNA. - Monographs in Systematic Botany from the Missouri Botanical Garden 98: 151-167.

\section{APPENDIX 1: VOUCHER SPECIMENS AND GENBANK}

\section{ACCESSION NUMBERS}

Mesoptychia igiana Buryatia 1, Russia (3.VIII.2013, Mamontov 392-3, LE): KR138592; Mesoptychia igiana Buryatia 2, Russia (3.VIII.2013, Mamontov 386-5, MHA): KR138593; M. badensis Scotland 1, UK (27.III.2007, Flagmeier \& Chamberlain s.n., E): KC305699; M. badensis Scotland 2, UK (27.III.2007, Chamberlain \& Flagmeier s.n., E): JX305561; M. collaris Slovakia (Hentschel Bryo 0864, GOET): DQ312501; M. collaris Switzerland (19.VIII.2008, Cailliau 800): JX305558; $M$. bantriensis Scotland, UK (Long 34172, E): JF513458; M. heterocolpos Utah, USA (1.VIII.2004, Stotler \& Crandall-Stotler 4357, ABSH): DQ268972; M. heterocolpos Sweden (1.VIII.2009 Cailliau \& Loennell 986): JX305559; $M$. aff. heterocolpos Sweden (1.VIII.2009, Cailliau \& Loennell 985): JX305560; M. heterocolpos var. harpanthoides Sweden (1.VIII.2009, Cailliau \& Loennell 976): JX305566; M. heterocolpos Switzerland (30.VI.2008, Cailliau et al. 750): JX305567; M. morrisonicola China (22.X.2004, Long 33526): JX305568; M. rutheana JX305578; M. rutheana Russia (14.VIII.1994, Konstantinova \& Schuster s.n.): JX305569; M. turbinata Switzerland (11.IX.2008, Cailliau 844): JX305570; M. gillmanii UK (1.VIII.1993, Long 24667): JX305565; M. fitzgeraldiae UK (22.VII.2008, Rothero 883): JX305564; M. bantriensis Switzerland (2.VII.2008, Cailliau et al. 770): JX305562; Jungermannia atrovirens Switzerland (Z. Hrad lek, DUKE ): KF852398; J. exsertifolia subsp. cordifolia Alaska, USA (Shaw F951/5, DUKE): KF943592. 